\title{
POŁOŻENIE KLASOWO-WŁASNOŚCIOWE GRACZY W PROFESJONALNYCH SPORTACH DRUŻYNOWYCH
}

Jakkolwiek sport jako taki, a sporty zespołowe w szczególności od dawna przyciągają uwagę badaczy, nadal pewna kluczowa problematyka pozostaje zasadniczo poza polem widzenia nauk społecznych. Dotyczy to węzłowego zagadnienia, jakim jest pozycja klasowa zawodowych graczy w takich popularnych dyscyplinach sportu, jak piłka nożna, futbol amerykański, baseball czy koszykówka. Zasadność tego sądu zależy oczywiście od tego, jak rozumie się pojęcie klasy społecznej, dlatego też od wyjaśnienia tegoż rozpoczynamy artykuł, wskazując na jego zakorzenienie w socjoekonomicznie pojmowanych stosunkach własności. Ujęcie tej ostatniej jako renty zobowiązuje natomiast do wyjaśnienia stosunku naszego pojęcia do znanego konceptu renty ekonomicznej. Już te rozważania rzucą sporo światła na sytuację klasową zawodników w sportach drużynowych, która to analiza zostanie wzbogacona i skonkretyzowana dzięki zastosowaniu zespołu kryteriów służących do rozróżniania realnej i nominalnej własności kapitału.

Autor artykułu wypracował własną koncepcję klas, zawdzięczającą jednak wiele dorobkowi wielkich poprzedników - można argumentować, że istnieją tylko dwie klasyczne teorie klas: te sformułowane przez Karola Marksa i Maksa Webera, a wszystkie pozostałe są w większym lub mniejszym stopniu komentarzami czy glosami do tych pierwotnych „kamieni węgielnych”. Przynaglani dodatkowo limitami objętości tekstu, nasz przegląd różnych teorii klas ograniczymy właśnie do tych dwóch klasycznych ujęć, czego dodatkową zaletą będzie wyeksponowanie - zwykle zapoznawanego wątku - znacznej zbieżności perspektyw obu wielkich rywali. 


\section{Weberowskie pojęcie klasy ekonomicznej}

Jak to normalne u niemieckiego socjologa, teoria klas zostaje przedstawiona $\mathrm{w}$ formie logicznie ze sobą powiązanych definicji. Punkt wyjścia tej piramidy stanowi określenie położenia klasowego jako typowej szansy:

- zaopatrzenia w dobra,

- zewnętrznej pozycji życiowej,

- wewnętrznego losu życiowego.

Wynika ona z rozmiarów i rodzaju władzy rozporządzania dobrami czy zdolnością do świadczeń (lub jej braku) oraz z istniejących możliwości ich spożytkowania do osiągnięcia dochodu lub przychodów w ramach danego porządku gospodarczego.

Literalnie rzecz biorąc, nie ma tu mowy o stosunkach własności, a jednak to one stanowią podstawowy budulec całej omawianej teorii. Dotyczy to nie tylko pierwszej, lecz i obu następnych wprowadzanych przez autora Gospodarki i społeczeństwa definicji.

Klasą nazywa on „każdą grupę ludzi znajdujących się w jednakowym położeniu klasowym”. Klasą posiadania określa „daną klasę wtedy, gdy położenie klasowe określają głównie różnice posiadania” ${ }^{1}$, klasą zarobkową zaś „daną klasę wtedy, gdy położenie klasowe określają głównie szanse rynkowego spożytkowania dóbr lub świadczeń".

Jak zaznaczano, różnica między tymi dwoma typami klas nie polega bynajmniej na tym, że pierwszy z nich jest, a drugi nie jest wyznaczany przez własność, wskazuje na to jednoznacznie enumeracja grup zaliczonych przez Webera do obu kategorii, jakiej ze względu na konieczność oszczędnego obchodzenia się z „przestrzenią drukarską" nie da się tutaj zreprodukować.

Pozytywy, by wymienić jeden tylko przykład, nazwane tak przez Webera negatywnie uprzywilejowane klasy zarobkowe składają się z robotników, różniących się jakościowo ze względu, dopowiedzmy, na rodzaj czy poziom posiadanej siły roboczej:

- wykwalifikowanych,

- przyuczonych,

- niewykwalifikowanych.

Zarówno w realnych socjoekonomicznych kategoriach, ale często nawet nominalnie klasy zarobkowe nie różnią się od klas posiadania tym, że przysługują im pozawłasnościowe determinanty, a jedynie inny rodzaj tych determinant; tym ostatnim klasom własność stwarza możność życia bez pracy; jak pisze Weber: „posiadaczem będziemy nazywać [...] osobę, która (normalnie) n i e uczestniczy z konieczności,

1 M. Weber, Gospodarka i społeczeństwo. Zarys socjologii rozumiejącej, PWN, Warszawa 2002, s. 228. 
czy to kierując, czy pracując, w procesie pracy. Może ona, jako posiadacz, być kierownikiem, ale nie jest to konieczne i bardzo często nim nie jest”.

\section{Marksowska koncepcja klas}

Można śmiało zaryzykować twierdzenie, że w całym rozległym obszarze nauk społecznych niewiele jest koncepcji, które budziłyby jednocześnie tyle kontrowersji i nieporozumień co teoria klas Marksa. Jedną z zasadniczych przesłanek tego stanu rzeczy jest daleki od jednoznacznego definicyjnego wykładu, jaki spotykamy u Webera, kształt owej teorii. W przypadku Marksa musi być ona rekonstruowana na podstawie wyrywkowych i rozproszonych twierdzeń, których interpretacja może być podważona przez innych komentatorów. To m.in. tłumaczy uporczywą popularność poglądu łączącego Marksa z dwubiegunowym modelem struktury klasowej. Źródło tej interpretacji stanowi znany ustęp z Manifestu komunistycznego, który przy wszystkich swych literackich i propagandowych zaletach był jednak, nie wolno zapominać, dokumentem w pierwszym rzędzie politycznym i ideologicznym, a nie dziełem naukowym. W pracach historycznych Marksa odnajdujemy zarys znacznie bogatszej perspektywy niż model dwu antagonistycznych klas. Faktem jest, że nie układają się one w żaden systematyczny wykład, a zamiar Marksa zdefiniowania pojęcia klasy społecznej pozostał niespełniony. Warto jednak owej próbie przyjrzeć się bliżej.

W III tomie Kapitału Marks przejmuje, jako punkt wyjścia dla budowy własnej teorii, koncepcję klas klasycznej ekonomii politycznej dzielącą społeczeństwo na trzy podstawowe klasy wedle ich źródeł dochodu: płacy, zysku lub renty. Marks stawia pytanie, co stanowi źródło jedności tych klas i odpowiada, że na pierwszy rzut oka wspólne źródło dochodów. Nie uznaje jednak tej odpowiedzi za zadowalającą. Argumentuje, że przyjęcie takiego poglądu pociągałoby za sobą konieczność wyróżnienia niezliczonych „klas”, bo przecież szewcy mają inne źródło dochodu od krawców, lekarze różnią się pod tym względem od adwokatów itd., itp. Niestety, sam Marks nie zdążył udzielić definitywnej odpowiedzi na tak postawione pytanie. Z perspektywy stanowiska teoretycznego obecnego autora, noszącego nazwę strukturalizmu socjoekonomicznego (jakie nie wiadomo czy pokrywa się ze stanowiskiem Marksowskiego materializmu historycznego, a już na pewno nie pokrywa się z poglądami dużej części marksistów), nie ma wątpliwości, iż rozwiązanie tej „zagadki” tkwi w ekonomiczno-socjologicznie rozumianych stosunkach własności. Doszliśmy już do tej tezy, analizując teorię Maksa Webera. Nie powracając już do tej dyskusji, 
poświęćmy chwilę refleksji jednemu z kontynuatorów Marksa, który w odróżnieniu od autora Kapitału sformułował expressis verbis definicję klasy społecznej.

Chodzi oczywiście o znaną definicję Włodzimierza Lenina, która określa mianem klas „,wielkie grupy ludzi, różniące się między sobą miejscem zajmowanym w historycznie określonym systemie produkcji społecznej, stosunkiem (przeważnie utrwalonym i usankcjonowanym przez prawo) do środków produkcji, rolą w społecznej organizacji pracy i co za tym idzie sposobem otrzymywania i rozmiarami tej części bogactwa społecznego, którą rozporządzają. Klasy to takie grupy ludzi, z których jedna może przywłaszczać sobie pracę drugiej dzięki różnicy miejsca, jakie zajmują w określonym systemie gospodarki społecznej"2. Powyższa definicja nie jest wolna od pewnych uproszczeń, zrozumiałych ze względu na kontekst; ma też jednak zalety: dzięki wprowadzeniu do definicji terminu „system gospodarki społecznej” zwraca ona uwagę na konieczność dostrzegania istnienia klas poza sferą samej produkcji, choć nie - gospodarki. Nie tyle z samej definicji, co innych prac, zwłaszcza empiryczno-badawczych, wynika, że pod występującym w przytoczonym określeniu klas niejednoznacznym pojęciem stosunku do środków produkcji Lenin rozumiał stosunek własności, własności odróżnianej przy tym od jej prawnego wyrazu oraz, co ma wielkie znaczenie, obejmującej siłę roboczą. To ostatnie wynika choćby z innego twierdzenia w tym samym tekście, w którym Lenin uznaje, że dla całkowitego zniesienia klas konieczna jest nie tylko likwidacja prywatnej własności środków produkcji, lecz również zniesienie podziałów między miastem i wsią (czyli wielkimi dziedzinami społecznego podziału pracy) oraz między pracownikami fizycznymi i umysłowymi.

Jeśli idzie o inne elementy definicji Lenina, to problem klas jako „wielkich grup” podejmiemy, wprowadzając dwuszczeblowe ujęcie klas, gdzie od klas właściwych odróżnia się megaklasy, czyli klasy zagregowane: są to pojęcia budowane na podstawie wspólnych cech łączących kilka klas, np. megaklasa kapitalistyczna obejmuje klasę kapitalistów przemysłowych, handlowych, burżuazję finansową itd.

Natomiast nie będziemy się wdawać $\mathrm{w}$ deliberacje, na ile określenie mówiące o przywłaszczaniu sobie pracy innej klasy jego autor uznawał za konieczny, a na ile jedynie warunkowy element definicji klasy, stanowisko strukturalizmu socjoekonomicznego wyklucza bowiem jednoznacznie sprowadzanie stosunków klasowych do relacji antagonistycznych ze względu na powszechne występowanie w historycznych społeczeństwach klasowych grup niewchodzących w relacje bezpośredniego wyzysku czy to jako podmiot, czy obiekt (klasy samodzielnych drobnych posiadaczy, chłopów i rzemieślników przeważały np. w klasycznym okresie starożytności greckiej).

2 W. Lenin, Dzieła, t. 29, KiW, Warszawa 1956, s. 4156. 


\section{Definicja klasy i własności}

Powyższe rozważania wskazują, że klasy społeczne należy wyróżniać na podstawie różnic miejsca zajmowanego przez dane grupy ludzi w strukturze stosunków własności środków produkcji, wymiany, usług i finansów oraz siły roboczej. Obsługiwane przez siłę roboczą materialne i idealne warunki pracy w poszczególnych dziedzinach gospodarki można objąć ogólną nazwą środków gospodarowania lub Weberowskim terminem środków zaopatrywania. Komentarza wymaga kluczowe dla tej definicji pojęcie własności. Jest tu ona rozumiana, po pierwsze, jako stosunek (socjo)ekonomiczny, w odróżnieniu od prawnych form, jakie odzwierciedlają i zwrotnie oddziałują na bazowe stosunki własności. Treść pojęcia własności nieźle oddaje określenie „własność beneficjalna” sformułowane w przełomowym traktacie, jaki zrewolucjonizował dwudziestowieczne myślenie o związkach korporacji i własności prywatnej. Jednak ujęcie takie byłoby niepełne - należy podkreślić, że korzyści, jakie zapewnia własność, mają zawsze w mniejszym lub większym stopniu charakter gratisowy, co sprawia, że prezentowane tu ujęcie najlepiej charakteryzuje określenie „rentowa koncepcja własności”, nawiązujące do pojęcia renty jako niezarobionego dochodu; jak objaśnia inny zwolennik takiego podejścia, „ten typ dochodu określa się często jako rentę, ponieważ jakaś część korzyści z własności należącej do danej jednostki jest uzyskiwana niezależnie od wysiłku oraz wszelkich działań danego podmiotu w przeszłości”.

\section{Wynagrodzenia graczy a renta ekonomiczna}

Istotne jest, by nie utożsamiać powyższego ujęcia renty z właściwym obiegowej ekonomii podręcznikowej pojęciem renty ekonomicznej. By się o tym przekonać, przyjrzyjmy się bliżej konceptowi właściwemu ekonomii neoklasycznej - Sorensen powiada, że badacz rynku pracy powinien objaśnić trzy różne wielkości: (1) Ya, płace aktualnie płacone na rynku; (2) Yc, płace, jakie płacono by w warunkach konkurencji doskonałej; (3) rentę, określoną jako:

$$
r c=Y a-Y c^{3}
$$

3 A. Sorensen, Towards a Sounder Basis for Class Analysis, „American Journal of Sociology” 2000, Nr 105(6), s. 152. 
Sorensen wywodzi dalej, że badacze klas społecznych powinni wyjaśniać prawidłowości w dziedzinie nierówności społecznych w kategoriach aktywów przynoszących rentę, skonceptualizowanych bardzo ogólnie, a nawet ogólnikowo czy, jak zauważa Wright, „zbyt abstrakcyjnie”, jako pozycje strukturalnie uprzywilejowane.

Tym, co uderza w powyższej definicji, jest przede wszystkim fakt, iż porównuje ona wielkości empiryczne z takimi $(Y c)$, które przynależą raczej do platońskiego czy Popperowego świata idealnego, odnoszącymi się do warunków tak wyidealizowanych, że niespotykanych nigdzie w świecie realnym, co rzuca się w oczy tym bardziej że organizują rozgrywki futbolu amerykańskiego NFL, jak inne profesjonalne ligi drużynowe cieszą się szeregiem zwolnień od obowiązującego prawa monopolowego, wskutek czego, jak i innych nadawanych im przywilejów objawiają one silne monopolowe i monopsonowe własności.

Nie jest rzeczą niezwykłą w myśli burżuazyjnej, że owemu idealizmowi obiektywnemu towarzyszy idealizm subiektywny nieodłączny od wielu, jeśli nie wszystkich definicji dążących do uszczegółowienia pojęcia renty ekonomicznej. Typowymi składnikami wspomnianych definicji są takie pojęcia, jak dochód transferowy, tj. minimalna płatność wymagana do utrzymania czynnika produkcji w jego aktualnym zastosowaniu, czy koszt utraconych możliwości, tzn. dochodów utraconych w wyniku zatrudnienia czynnika w danym zastosowaniu.

Metodologia właściwa teorii renty ekonomicznej reprezentuje subiektywizm w podwójnym sensie: przyjmowania w charakterze punktu odniesienia indywiduum, podmiotu decyzji i działania oraz arbitralności. Wskazanie, co w przypadku piłkarza stanowi „drugą najlepszą alternatywę” determinującą koszt utraconych szans, nie jest rzeczą łatwą; dla przykładu, chcąc ustalić, w jakim stopniu aktualny kontrakt przodującego we wszelkich piłkarskich rankingach napastnika Realu Madrid, Christiano Ronaldo, wyraża rentę ekonomiczną, czy powinniśmy porównywać ten pierwszy z hipotetyczną umową w innym klubie hiszpańskim tej samej, może niżej ligi? W innym klubie jednej z międzynarodowych lig? A może, biorąc pod uwagę doskonałe warunki zewnętrzne Ronaldo, mielibyśmy przewidywać dla niego karierę w filmie? Popularność Ronaldo na pewno też uczyniłaby go wymarzonym pracownikiem działu marketingu każdego koncernu produkującego artykuły sportowe, a mógłby on wszak teoretycznie wybrać np. intratną karierę zawiadującego funduszem hedgingowym itd.

Fakt, iż ramy teoretyczne konwencjonalnej koncepcji renty ekonomicznej są skazane na natrafienie na rafę tak pojętego subiektywizmu, potwierdza następująca

4 E. Wright, Class, Exploitation and Economic Rents: Reflections on Sorensen's Better Foundations, „American Journal of Sociology" 2000, Nr 1056, s. 1559. 
przykładowa definicja: „Renta ekonomiczna jest to płatność otrzymywana przez czynnik produkcji ponad tę, która jest niezbędna dla utrzymania go w obecnym zastosowaniu; tj. jest to suma, jaką ktoś może zarobić ponad swój zarobek transferowy (czyli to, co mógłby zarobić gdzie indziej)".

Sformułowanie „zarobić gdzie indziej” jest niesłychanie pojemne i naturalnie daleko zbyt obszerne, aby służyć jako narzędzie identyfikacji przedmiotowych odnośników pojęcia, do którego wedle zwolenników rozpatrywanego podejścia się odnosi.

Dalsza specyfikacja przytoczonej powyżej definicji stwierdza, iż: ,jest to określona przez popyt nagroda dla pracy, jaką uzyskuje się, gdy podaż pracy jest choć w pewnym stopniu nieelastyczna”. Jeśli nawet - zastępując "pracę" siłą roboczą - zgodzić się, że twierdzenie to wyraża pewne rzeczywiste zależności, to i tak są tu one skonceptualizowane zbyt abstrakcyjnie, by dać się bezpośrednio przełożyć na język konkretnej analizy. Jakie są źródła owej nieelastyczności? Unikalny wrodzony talent czy społecznie ustanowione bariery wejścia to zaledwie dwie zasadniczo różne możliwości. I szerzej, ta linia rozumowania odsłania kolejny aspekt metodologicznego indywidualizmu właściwego obiegowemu podejściu do renty ekonomicznej - dla socjologa jest oczywiste, że w realnym świecie to nie żadne formalne definicje płatności transferowej określają minimalny poziom płac, poniżej którego zawodnicy nie zgodzą się grać i będą w zamian strajkować, lecz proces prowadzonego przez związek zawodowy przetargu zbiorowego, oznaczający w kategoriach strukturalizmu socjoekonomicznego pewnego rodzaju uspołecznienie (kolektywizację) własności siły roboczej danych zawodników.

Epistemologiczny liberalizm i spekulatywizm nieodłączne od podręcznikowego ujęcia renty ekonomicznej tłumaczą, że podczas gdy jeden ekonomista może dowodzić, że „większość piłkarzy nadal uprawiałaby futbol za 80 tys. USD rocznie zamiast 800 tys. USD albo 8 mln USD”, co oznacza, że „każdy dolar ponad 80 tys. USD stanowi czystą nadwyżkę" ${ }^{\prime}$, to inny potrafi twierdzić, iż Cristiano Ronaldo (lider listy najwyżej opłacanych piłkarzy z 2014 r. sporządzonej przez magazyn „Forbes” z zarobkami szacowanymi na $80 \mathrm{mln}$ USD) „byłby gotów grać za jedynie 30 tys. USD na rok (jego dochód transferowy), co znaczy, że Ronaldo uzyskuje „rentę ekonomiczną w wysokości 26,000,000 - 30,000 = 25,970,000 USD na rok". Rezultat ten wynika ze sposobu oszacowania transferowej ceny siły roboczej Ronaldo jako wynagrodzenia za „ciężką pracę i trudne szkolenie" gał odeń żadnych poświęceń - nie kosztował on go nic, bo się z nim urodził. Przy

5 Definicja „economic rent” w: Free Online Dictionary.com

6 Player salaries and economic rents, „Monday” 12 July 2010, SmartFootball.com

7 Lecture 17: Economic Rents and Rent Seeking, EC101 DD \& EE 2015. 
okazji, stawia to pod znakiem zapytania powszechne stosowanie w literaturze sportowej jako kategorii generycznej terminu „talent”, a nie siła robocza.

W efekcie w literaturze tej co rusz spotyka się tego rodzaju illogiczne twierdzenia: „w klubach powstały dwie różne strategie, albo: i) same produkują talenty [...]”, gdy tymczasem, na mocy definicji, talentu nie traktuje się jako rzeczy nabytej. Powyżej wspomniana powszechna praktyka językowa daje się zatem traktować w najlepszym razie jako „druga najlepsza alternatywa”, jaka nosi charakter ideologiczny, gdyż pojęcie talentu ma przecie silnie wartościującą wymowę.

Proponowana tu kategoria siły roboczej góruje teoretycznie i empirycznie także nad innymi pojęciami występującymi w kontekście teorii renty ekonomicznej - zgodnie z jednym z takich uproszczonych, zdroworozsądkowych poglądów „gracz zarejestrowany w danym klubie stanowi część jego majątku". Otóż istot ludzkich jako takich nie da się przekształcić w element majątku czy aktywów jakiejkolwiek spółki bądź firmy; równie mylący jest popularny termin kapitału ludzkiego także stosowany przez autorów ww. dzieła. Bliższa analiza wykazuje, że pod pojęciem tym kryje się w rzeczywistości siła robocza, która w warunkach kapitalistycznego sposobu produkcji istotnie funkcjonuje jako kapitał, ale zmienny.

Ogniskować się na - na pierwszy rzut oka wygórowanych - wynagrodzeniach gwiazd sportu to ułatwiać i upraszczać sobie zadanie; z jednej strony autorzy tacy zaświadczają, że idą z duchem czasu (czytaj: aktualnej mody na krytyczne wypowiadanie się o nierównościach), podczas gdy w rzeczywistości unikają podejmowania tematów trudnych i drażliwych, takich jak ostateczne źródła i siły napędowe zjawisk obserwowanych na powierzchni życia ekonomicznego: stosunki własności i władzy w społeczeństwie kapitalistycznym. Także literatura opisująca zarobki sportowców w kategoriach renty ekonomicznej grzeszy nader często powierzchownością, przejawiającą się m.in. dziwnym wrażeniem, jakie ma czytelnik tej literatury, jakoby sporty drużynowe uprawiały jakieś odcieleśnione istoty. W tym punkcie pojęcie siły roboczej ponownie wykazuje swoją użyteczność analityczną. Można utrzymywać, że gracze w piłkę pobierają renty, ale przecież nie można ich utożsamiać z klasą rentierów - przede wszystkim dlatego, że swoje zarobki wypracowują sobie sami nogami i głową na murawie, a twierdzenie, iż owo wynagrodzenie za pracę ma w części charakter niezarobionego dochodu, jest rezultatem późniejszej analizy, niebędącej w stanie podważyć owego elementarnego faktu.

Tego ostatniego poglądu można istotnie bronić o tyle, że całkowite dochody piłkarzy i innych sportowców zawierają niezarobione składniki, uwarunkowane przez pracę jedynie $\mathrm{w}$ tym sensie, że dotyczące czynnych (obecnie lub w przeszłości) graczy. W 2011 r. David Beckham uzyskał łączny dochód wynoszący $46 \mathrm{mln}$ USD, z czego $37 \mathrm{mln}$ pochodziło od różnych sponsorów. Gwiazdor wtedy klubu Galaxy 
z Los Angeles wysforował się dzięki temu na pierwsze miejsce dorocznej listy najlepiej zarabiających piłkarzy. Piłka nożna jako najpopularniejsza dyscyplina sportu na świecie stanowi najbardziej atrakcyjny magnes dla kapitalistycznych korporacji; na graczy corocznie sypie się grad pieniędzy od sponsorów, liczący sobie dobrze ponad $250 \mathrm{mln}$ USD. By zilustrować doniosłość dochodu z, jak ją można nazwać, wartości symbolicznej bądź charyzmatycznej w odróżnieniu od wartości użytkowej zawodniczej siły roboczej, stanowiącej nieodłączny aspekt ich występów na boisku, w łącznej sumie $256 \mathrm{mln}$ USD, które dziesięć największych gwiazd sportu zarobiło w 2011 r., aż 43\% (111 mln USD) stanowiły sumy pochodzące od koncernów takich jak Adidas, Nike, Puma, Pepsi czy EA Sports.

Jak zauważono, czołowy zawodnik może na swoim wizerunku zbić majątek, ale wartość ekonomiczna owego wizerunku jest uwarunkowana faktem czynienia przez niego/nią praktycznego, nie jedynie symbolicznego użytku ze swej siły roboczej. Jest to istotne o tyle, że siła robocza graczy podlega nieuchronnemu zużyciu, którego namacalnym przejawem są liczne kontuzje i obrażenia (w tym urazy głowy i wstrząsy mózgu, będące plagą zwłaszcza w futbolu amerykańskim, gdzie prowadzą one często do nieodwracalnych zmian neurologicznych), na które narażona jest siła robocza graczy.

Ogólniej mówiąc, np. w tej ostatniej dyscyplinie wedle oficjalnych źródeł przeciętny okres trwania kariery zawodowej gracza wynosi zaledwie 3,3 roku. Ten bardzo krótki czas aktywnej kariery przeciętnego gracza NFL Player jest bardzo istotny; alternatywna ścieżka kariery, wedle sugestii cytowanych wyżej definicji, mogłaby wprawdzie przynosić futboliście niższe dochody w skali miesięcznej lub rocznej, lecz w sumie cała aktywna kariera zawodowa trwałaby o wiele dłużej, owocując wyższą łączną sumą dochodów. Bardzo trudno byłoby udowodnić, że z finansowego punktu widzenia zarabianie około 400 tys. USD rocznie przez 3-4 lata, by potem stracić perspektywy na dalszą karierę, stawia kogoś w lepszej sytuacji niż rozpoczynanie od posady z wynagrodzeniem 70 tys. USD na rok, gwarantującej jednak stabilny wzrost w przyszłości. Inny ważny socjologiczny wniosek płynący z krytyki schematów konstruowanych przez ekonomistów dotyczy konieczności uwzględniania konkretnego miejsca zajmowanego przez daną jednostkę w strukturze zróżnicowania społecznego; nie można porównywać zarobków np. gracza ligi futbolu amerykańskiego z wynagrodzeniami urzędnika czy celnika. Strumień dochodu tego pierwszego wykazuje więcej podobieństw do tego, jaki cechuje artystę lub nawet przedsiębiorcę - zmienny w czasie zależnie od powodzenia, stwarzający szanse wysokich zysków, lecz i ryzyko bankructwa. W rzeczy samej, wedle SI.com „dwa lata po wycofaniu się z czynnego uprawiania sportu $78 \%$ byłych graczy NFL stało się finansowymi bankrutami, a w najlepszym razie miało poważne problemy finansowe". Rozpatrywane 
osobliwości rozkładu dochodów w czasie mają jednak również inne konsekwencje rzutujące na sytuację finansową sportowców. Jeżeli ktoś otrzymuje określoną sumę pieniędzy jednorazowo, to płaci on/ona znacznie wyższą kwotę podatków niż zarabiający tyle samo, ale w sposób rozłożony względnie równomiernie w ciągu pewnego czasu, a owe wyższe kwoty opłacanego podatku dochodowego są jedynie w części równoważone przez efekt regresywnych narzutów nakładanych na wynagrodzenia, takich jak ubezpieczenia socjalne i zdrowotne. Tego rodzaju względy nie mogą nie wpływać na rzeczywiste możliwości uzyskiwania przez zawodników środków utrzymania i kiepsko harmonizują ze stanowiskiem uznającym przyswajanie renty ekonomicznej za główne źródło ich utrzymania.

Powyższe rozważania nie oznaczają bynajmniej, że wynagrodzenia zawodników sportów drużynowych są pozbawione elementów renty, tyle że należy ich z naszej perspektywy poszukiwać gdzie indziej - nasze ujęcie renty implikuje, że rentowy charakter mają różne elementy związane ze społeczną produkcją i reprodukcją danej siły roboczej: szkolenia, treningi, opieka medyczna, które wymagają nie tylko wysiłku, ale i wiedzy, często naukowej, wielu ludzi.

Jako bardzo przybliżoną miarę tego rodzaju uspołecznienia własności siły roboczej w sporcie można przyjąć liczbę przedstawicieli sportów zespołowych na listach magazynu „Forbes” obejmujących najlepiej opłacanych zawodników w 2015 r. Wprawdzie naturalnie $\mathrm{w}$ trofea np. tenisistów niemały wkład ma medycyna i nauka, lecz przy obecnym porównaniu wolno przyjąć, że podobnie dzieje się także w koszykówce i wszelkich innych dyscyplinach zespołowych, co uprawnia do zastosowania klauzuli „przy pozostałych warunkach jednakowych”. Jak się okazuje, w dziesiątce pierwszych sportowców na liście dokładnie połowa reprezentuje sporty zespołowe: piłkę nożną i koszykówkę.

Ponadto można mówić o uspołecznieniu siły roboczej posiadanej przez graczy o tyle, że np. wartość Ronaldo jako piłkarza, a zatem i jego wynagrodzenie są uwarunkowane jakością siły roboczej i jej praktycznej realizacji na boisku przez innych graczy jego doborowego zespołu; wątpliwe, czy jego ogromny talent miałby takie samo pole do popisu w jakiejś trzecioligowej drużynie.

Warto podkreślić, że rozwinięte tu ujęcie renty jest zgodne ze stanowiskiem Alfreda Marshalla wyłożonym w jego najsłynniejszym dziele z 1890 r. (Book Five: General Relations of Demand, Supply and Value, Chapter 11: Marginal Costs in Relation to Urban Value), wedle którego pojęcie renty odnosi się do „tych dochodów czy raczej tych ich części, jakie stanowią pośredni rezultat ogólnego procesu postępu społeczeństwa”. To samo pojęcie własności jako gratisowej korzyści, jakie akcentowano powyżej, jest też co najmniej implicite zawarte w słynnej teorii firmy, jaką sformułował Ronald Coase. Pojęcie firmy jako struktury pozwalającej na oszczędności 
na kosztach transakcyjnych można w tym sensie postawić obok Marksowskich analiz różnorakich darmowych korzyści płynących z przemysłowego zastosowania maszyn albo różnych stron społecznego, w tym wewnątrzzakładowego podziału pracy. Ogólniej biorąc, współcześni ekonomiści przypominają często molierowskiego pana Jourdain z komedii Le bourgeois gentilhomme, nieświadomego, że przez całe życie mówił prozą, o tyle że w istocie nie rozpatrują oni nic innego, jak ekonomiczną własność pod szyldem tzw. dodatnich efektów zewnętrznych, która to kategoria stanowi żelazny element zestawu narzędziowego ekonomii głównego nurtu.

Zgodnie z również standardową definicją, umowa zbiorowa jest określana jako porozumienie wyrażające stosunek zatrudnienia między pracodawcą a pracownikami, różniący się zależnie od rodzaju dyscypliny, jednakże obejmujące zawsze pewne standardowe elementy: sankcje dyscyplinarne, wynagrodzenie, urlopy, czas pracy itd. Z takiej perspektywy piłkarzy czy koszykarzy należałoby traktować jako najemnych pracowników sfery usług, jako że sport generalnie jako dziedzina rozrywki wchodzi w skład sektora usług. Poniższa analiza wykazuje jednak, jak uproszczony byłby to pogląd.

\section{Wynagrodzenia graczy a ich pozycja własnościowo-klasowa}

Jednostronność wspomnianej wyżej koncepcji zostanie dowiedziona za pomocą osadzonego w socjoekonomicznym ujęciu własności rozróżnienia między realną a nominalną własnością kapitału; w kontekście pracowników sens tej ostatniej oddaje pojęcie dodatku do płacy występującego pod inną formalnie nazwą, np. dywidendy. Podstawową przesłanką wymienionej opozycji stanowi pogląd, zgodnie z którym nie wszystkie bynajmniej np. pakiety akcji wyrażają realną ekonomiczną własność kapitału akcyjnego, dotyczy to tylko pewnej ich części spełniającej ściśle określone kryteria. Jeden $\mathrm{z}$ tych warunków stanowi np. możność przekształcenia analizowanej sumy we własność środków produkcji rzeczywistego przedsiębiorstwa, czyli stanie się de facto kapitalistą. Współtowarzyszącą przesłankę analityczną stanowi teza uprawniająca do ujmowania w kategoriach kapitału wielkości na pierwszy rzut oka odeń odległych, np. płac.

Wśród sportów drużynowych na świecie najwyższymi zarobkami wedle agencji Sporting Intelligence mogą się poszczycić koszykarze grający w amerykańskiej lidze NBA: średnio 4,6 mln USD w sezonie 2014-1915. 
W tym rankingu liga koszykówki NBA posiada strukturalny atut w postaci stosunkowo niewielkiej liczebności drużyn - zaledwie 448 graczy ligi podzieliło między siebie łączną sumę 2,1 mld USD stanowiącą pulę ich łącznych pensji. Dlatego chociaż gracze ligi futbolu amerykańskiego NFL zbiorowo zarobili aż 3,6 mld USD w 2014 r., kwota ta musiała zostać rozdzielona pomiędzy 1684 zawodników, co dało im średnie wynagrodzenie w wysokości „tylko” 2,1 mln USD, czyli dopiero czwarte miejsce wśród głównych północnoamerykańskich lig sportowych.

Pouczające jest również porównanie powyższych liczb z danymi zebranymi przez Sporting Intelligence w jej raporcie pt. Global Sports Salaries Survey for 2015', zgodnie z którym najlepiej opłacana drużyna w światowym sporcie to paryska Saint-Germain. Przeciętne wynagrodzenie w pierwszym zespole PSG to 5,3 mln $£$ na rok $(8,3 \mathrm{mln}$ USD) w analizowanym okresie. O ile w tym oraz w co najmniej niektórych rozpatrywanych przypadkach wysokie wynagrodzenia da się traktować jako wynagrodzenia za efekty pracy czy jako swoisty akord grupowy, nagradzający cały zespół - PSG zdobyła tytuł mistrza kraju trzy razy pod rząd, można wątpić, czy klub byłby tak szczodry, gdyby jego kasy nie zabezpieczał mający z kolei oparcie w bogactwach naftowych właściciel - Qatar Sports Investments. Warto dodać, że naftowe kapitały władają bądź sponsorują wiele z najbogatszych klubów piłkarskich świata. Inne kluby najlepiej płacące swym zawodnikom często mają za swych właścicieli zwłaszcza rosyjskich i amerykańskich miliarderów zaangażowanych kapitałowo w sport na wielu frontach.

Wśród dwunastu najlepiej płacących graczom klubów przeważają kluby piłkarskie (osiem), które zajmują cztery najwyższe lokaty, trzy to kluby baseballowe, a jeden to drużyna koszykówki. W przekroju geograficznym, po czterech spośród tuzina najbogatszych pracodawców w sportach zespołowych wywodzi się z USA oraz Anglii, z Hiszpanii pochodzi dwóch, a po jednym z Niemiec i Francji.

Ogółem czołowa dwunastka obejmuje pięć klubów angielskiej Premier League, sześć drużyn z jednej z głównych lig (Baseball), a pięć to drużyny ligi koszykówki NBA.

Najbardziej zasobny z klubów piłkarskich Real Madryt zdobył srebrny medal w rozpatrywanej konkurencji, płacąc swym zawodnikom 5,04 mln $\mathfrak{E}$ na głowę rocznie, Manchester City spadł z pierwszego miejsca zajmowanego rok wcześniej na trzecią pozycję, za Realem, lecz ze średnią płacą wynoszącą wciąż $5 \mathrm{mln} £$ na głowę rocznie.

Przechodząc do szczegółowej identyfikacji statusu klasowego zawodników, dla których posiadamy niezbędne dane, warto rozpocząć od przodującego w rankingu zarobków graczy w piłkę nożną, Cristiano Ronaldo, czy jego burżuazyjny status nie może, zgodnie ze wzmiankowanymi wyżej kryteriami i danymi, ulegać najmniejszej wątpliwości. Wedle materiałów Banku Światowego (proces zbierania danych został 
zakończony w czerwcu 2014 r. $)^{8}$, spółka z ograniczoną odpowiedzialnością w Hiszpanii, prowadząca działalność przemysłową lub handlową i zatrudniająca 10-50 ludzi, potrzebuje w pierwszym miesiącu swego funkcjonowania 18,2 mln USD w formie kapitału wyjściowego, czyli przeszło czterokrotnie mniej od zarobków napastnika Realu.

Na szczeblu ligowym, przypomnijmy, zawodnicy NBA w sezonie 2014-2015 odebrali w klubowej kasie średnio 4,6 mln USD każdy, podczas gdy pensje futbolistów NHL wyniosły 2,1 mln USD.

Skupmy się na drugim z tych przypadków, gdyż jeśli uda się wykazać, że dane liczby reprezentują realną kapitalistyczną własność, to tym bardziej teza taka dotyczyć będzie poprzedniego przypadku, w którym odnośne sumy są wyższe. Posłużymy się w tym celu inną metodą z dostępnego nam wachlarza technik porównawczych. Otóż ściśle biorąc, wielkość płacowa, jaką przyjmujemy za podstawę szacunku, musi zostać zmodyfikowana, zanim będzie można ją zestawiać z kapitałem. Należy zatem od wyjściowej sumy odjąć wartość siły roboczej, jaką w obecnym kontekście wolno ująć jako społecznie przeciętną siłę roboczą, którą to wartość da się skalkulować jako średni poziom wydatków konsumenckich, mogący być uznany za odpowiednik społecznie przeciętnego kosztu reprodukcji siły roboczej (w USA i w innych społeczeństwach liczba żyjących z pracy znacznie przewyższa liczebność klas właścicielskich).

Tak „oczyszczona” suma może zostać skapitalizowana, co pozwoli ustalić, kapitał jakiej wielkości reprezentuje 2049 000, skapitalizowane przy stopie równej uzyskowi z dywidendy (dywidenda/cena akcji) w wysokości 2,38\%, daje w wyniku 8,61 mln USD. Oznacza to, iż powyższa hipoteza okazała się mylna; jakkolwiek wysoka, suma powyższa nie dorównuje tej, która została przyjęta jako odpowiednik realno-ekonomicznej własności kapitału: 8,8 mln USD, czyli ilość startowego kapitału wymagana do założenia firmy prywatnej w krajach OECD o wysokim dochodzie. Tak zatem to samo podejście zostanie zastosowane odnośnie do najlepiej płacącej sportowcom ligi w USA, tj. NBA, co daje w wyniku sumę 19,3 mln USD jako kapitałowy ekwiwalent średniej pensji w lidze. W świetle przyjętych kryteriów liczba ta jest ponad dwukrotnie wyższa niż próg minimum dla kapitalistycznej własności.

Zauważmy, że powodem, dla którego niektórym czytelniczkom traktowanie zawodników sportów zespołowych jako kapitalistów może wydawać się dziwne, jest fakt ich pracy zarobkowej, na pozór kolidujący z ich przynależnością do burżuazji. Reprezentując taki pogląd, nie bierze się jednak pod uwagę kluczowych własnościowo-ekonomicznych faktów, o których była wyżej mowa, a także pomija istnienie klas mieszanych, tj. łączących w swej charakterystyce cechy co najmniej dwóch klas; część sportowców może być uznana za aktywnych kapitalistów, nieco podobnie do

8 World Bank, Starting A Business 2015. 
produkcyjnej burżuazji, którą tworzy megaklasa menedżerska. Podobne kombinacje nie są wcale nowożytnym wynalazkiem; wystarczy wspomnieć niewolników starożytności, pozbawionych własności swej siły roboczej, lecz niejednokrotnie posiadających warsztaty lub inne środki produkcji.

Warto również podkreślić taką zaletę stosowanego tu podejścia, jak brak schematyzmu, dążenia do podciągania wszystkich rozpatrywanych zjawisk pod jeden strychulec; przeciwnie, zwracamy uwagę na socjo- i klasoróżnorodność poszczególnych spośród rozpatrywanych przypadków. I tak o ile kluby National Football League stać na płacenie swym graczom milionów dolarów co roku bez popadania w kłopoty finansowe, o tyle już druga co do ważności liga w tej samej dyscyplinie United Football League ma ustawicznie trudności z płaceniem swoich rachunków, mimo że płace jej graczy wynoszą tylko 20 tys. USD rocznie.

Ten przypadek reprezentuje zdecydowanie własność samej tylko siły roboczej. Przekonuje o tym choćby zestawienie wymienionej liczby z sumą podaną przez U.S. Bureau of Labor Statistics, reprezentującą średnie wydatki przypadające na jednostkę konsumpcji w 2013 r., które wyliczono na 51 tys. USD - niewiele zmienione od 2012 r. Kategorię tego rodzaju wydatków można z grubsza przyrównać do wartości społecznie przeciętnej siły roboczej. Podobnie, w 2009 r. Fundacja Kauffmanna oszacowała średni kapitał startowy na 30 tys. USD ${ }^{9}$, co oznaczałoby, że rozpatrywany powyżej warunek konwersji w tym przypadku także nie ma zastosowania. Oczywiście, można sobie wyobrazić setki drobnych biznesów, do których uruchomienia wystarczy nawet mniej niż powyższe 20 tys. USD, lecz są to w przeważającej, jeśli nie wyłącznej mierze jednoosobowe firemki, których bazą lokalową jest mieszkanie właściciela. Owi drobni posiadacze najczęściej nie zatrudniają nikogo, a więc nie mogą być traktowani jako kapitaliści. Tradycyjnie obejmowano ich nazwą drobnomieszczaństwa, ale uznając, że z wielu powodów określenie to przeżyło już swoją użyteczność i czas najwyższy zastąpić je nowym, pozbawionym wad poprzednika: np. nieuniknionego zabarwienia wartościującego, rozdźwięku pomiędzy zewnętrzną szatą werbalną terminu a faktem, że wielu przedstawicieli tej klasy zamieszkuje wsie, a nie miasta, co prowadzi do terminologicznej propozycji „klasy autokefalicznej”, który to termin zapożyczony został z socjologii religii Webera jako znacznie bardziej adekwatnie oddający taką cechę położenia klasowego danej grupy, jaką stanowi podwójna niezależność: od cudzego zwierzchnictwa oraz od cudzej pracy.

Tak jest oczywiście w czystym przypadku klas autokefalicznych - w realnym życiu społecznym spotykane są przypadki mieszane i przejściowe, o niepełnej własności

9 C. Beesely, How to Estimate the Cost of Starting a Business from Scratch, „Small Business Administration" 2015. 
środków gospodarowania i/lub siły roboczej. Takich właśnie „Zamazanych” sytuacji dotyczy informacja, którą podał Jerome Champagne, były numer dwa w FIFA, zgodnie z którą wśród 65 tys. zawodowych graczy istniejących obecnie na świecie 60 tys. jest niedopłacanych, ma wynagrodzenia wypłacane z opóźnieniami lub nawet w ogóle. Dotyczy to przede wszystkim tych licznych profesjonalnych graczy, którzy nie posiadają umów o pracę i działają na zasadzie samozatrudnienia przy minimalnych gwarancjach prawnych. „W Republice Czeskiej ogromna większość graczy to samozatrudnienie. Wedle badania FIFPro brak terminowych wypłat wydaje się stanowić zasadniczy problem w Grecji, Polsce i Słowenii" ${ }^{\prime \prime}$.

Ma się rozumieć, że takie osoby trudno uznać za przedstawicieli uprzywilejowanej klasy posiadającej; w istocie rzeczy ich rzeczywiste położenie jest bliskie sytuacji pracowników, tyle że znacznie gorsze, bo pozbawione tych aspektów, które czynią pracowników właścicielami swych miejsc pracy, które to wywłaszczenie koresponduje z częściowym wywłaszczeniem z posiadanej siły roboczej.

Powyższa wzmianka o niewolnictwie wraz z rozróżnieniem pomiędzy dwoma typami własności, których przedmiotem są, odpowiednio, siła robocza i warunki pracy, stanowi dogodny punkt przejścia do kolejnej części artykułu.

Należy zdawać sobie sprawę, że przez długi czas zawodowi gracze w wielu krajach byli przywiązani do swoich klubów, które sprawowały kontrolę nad ich siłą roboczą czy, w języku potocznym, karierą.

Tak więc np. w amerykańskiej lidze baseballu w 1879 r. wprowadzono system, który efektywnie przywiązywał wieczyście zawodnika do jego klubu - pod ochronnym parasolem zwolnienia z prawa antymonopolowego. System ten został przyjęty także przez inne główne ligi sportowe, co dobitnie ilustruje wymowna wypowiedź właściciela jednego z klubów NHL, Cleveland Browns: „było rzeczą zarazem słuszną i konieczną, by zarząd mógł redukować, handlować, przyjmować do zespołu, odsyłać na ławkę rezerwowych oraz posiadać wieczyście, kogokolwiek tylko chce"11.

W roku 1885 angielski związek piłki nożnej po raz pierwszy wprowadził pojęcie transferu, ustanawiając wymóg rejestrowania się w związku wszystkich graczy zamierzających zatrudnić się w którymś z klubów. Poprzednio zawodnicy znajdowali się w korzystnej pozycji przetargowej, pozwalającej im przenosić się z jednego klubu do drugiego w dowolnym czasie bez przeszkód, czyli dysponować własną siłą roboczą.

$\mathrm{W}$ warunkach nowego systemu wymagał od zawodnika, by zapisał się do jakiegoś klubu na dany sezon, nie dopuszczając tym samym do jego przenosin do innego

${ }^{10}$ KEA - CDES, Study on the economic and legal aspects of transfers of players, January 2013.

11 A. Piascik, The Best Show in Football: The 1946-1955 Cleveland Browns, Taylor Trade Publishing, Lanham, MD 2007. 
klubu bez zgody związku i obecnego klubu. Ten system licencji został wprowadzony we Francji w 1925 r. I tu podobnie do czasu jego wprowadzenia zawodnicy mogli bez przeszkód przenosić się z danego klubu do innego. Poczynając od lat 20. XX w., zawodowstwo rozpowszechniło się w całej Europie. Zatem wraz z systemem rejestracji zaistniał rynek transferowy, jako że uważano, iż klubowi należy się rekompensata po utracie zawodnika.

W Anglii do 1959 r. zawodowi gracze byli angażowani na podstawie jednorocznych kontraktów określających płacowe maksima i minima. Po wygaśnięciu kontraktu klub mógł zatrzymać zawodnika, oferując mu minimalne wynagrodzenie, przekazać go do innego klubu za opłatą lub unieważnić rejestrację gracza, umożliwiając mu tym samym stanie się tzw. wolnym agentem, czyli w kategoriach strukturalizmu socjoekonomicznego właścicielem swej siły roboczej. Klub sprawował więc całkowitą kontrolę nad warunkami zatrudnienia swoich zawodników.

Zatem wdrożony w lidze angielskiej w 1889 r., rok po jego utworzeniu system określający warunki „zatrzymywania i transferu” graczy - zbliżony do rozwiązań stosowanych w Ameryce Północnej - prowadził do ograniczenia własności siły roboczej zawodników. Sytuacja tych ostatnich była analogiczna do położenia feudalnych chłopów poddanych przypisanych do ziemi (w tym wypadku można by umownie mówić o murawie). Jeśli położenie chłopa feudalnego można przeciwstawić sytuacji robotnika w kapitalizmie, dowolnie rozporządzającego swoją siłą roboczą, to dopiero w 1976 r. gracze ligi baseballowej zdobyli prawo tzw. wolnej agencji, czyli swobodnego rozporządzania własną siłą roboczą, pod warunkiem zaliczenia sześcioletniego okresu zatrudnienia. Zwyczaj ten podchwyciły wkrótce inne podstawowe ligi sportowe, a w 1995 r. Europejski Trybunał Sprawiedliwości zadał poważny cios futbolowemu systemowi transferowemu funkcjonującemu podówczas na obszarze UE, ogłaszając jego niezgodność z art. 48 Traktatu rzymskiego, gwarantującego swobodę ruchu pracowników. Co się tyczy praktyki obowiązującej w USA, mobilność zawodników była tu ograniczona przez tzw. regułę Rozelle (nazwaną tak od nazwiska komisarza, który pierwszy ją zastosował), zezwalającą komisarzowi na kompensowanie klubowi utraty „,wolnego agenta” na rzecz innej drużyny poprzez dostarczenie mu dóbr o porównywalnej wartości, co w praktyce oznaczało najczęściej możliwość preferencyjnego wyboru nowych graczy podczas tzw. zaciągu kadrowego (draft) kosztem klubu docelowego transferowanego zawodnika, którego pozycja z punktu widzenia szans wyboru atrakcyjnych zawodników tym samym ulegała pogorszeniu. W konsekwencji obawa utraty owych cenionych opcji naboru graczy stanowiła potężną barierę dla zasady swobodnego ruchu graczy, jako że żaden klub nie chciał ryzykować przyjmowaniem weterana, by w zamian stracić prawo doboru świeżej młodej krwi podczas kolejnych dwóch czy trzech rekrutacji. Zasada Rozelle została 
zastąpiona „planem B”, który zezwalał każdej drużynie na wytypowanie 37 graczy objętych klauzulami ograniczającymi własność ich siły roboczej, która przysługiwała natomiast pozostałym. I znowu, jest oczywiste, że poza ową zastrzeżoną listą niewielu by znalazł graczy z górnej półki, chyba że przydarzyła się im kontuzja czasowo sprowadzająca do zera wartość użytkową ich siły roboczej. Ostatecznie sądy uznały te zasady za sprzeczne z prawem antymonopolowym, w czego wyniku w futbolu amerykańskim zapanowało coś zbliżonego do, trzymając się oficjalnego języka, „wolnej agencji” - obecnie wyłączne prawa do dysponowania siłą roboczą zawodnika dotyczą jedynie pierwszych trzech lat po naborze z uczelnianego zaciągu, z którego pochodzi gros graczy. Po zakończeniu pierwszego trzyletniego okresu zawodnik może być „ograniczonym wolnym agentem” (i tym samym równie ograniczonym właścicielem siły roboczej), w którego przypadku macierzysty klub ma prawo wysunąć własną kontrofertę wobec wszelkich propozycji, jakich by nie otrzymał jego zawodnik. Po czteroletnim stażu w NFL upłynięcie każdej umowy równa się uzyskaniu przez danego sportowca praw „nieograniczonego wolnego agenta”.

Nie wyczerpuje to wszelako panoramy stosunków własności siły roboczej, gdyż obok wymienionych istnieje również opcja licencjonowania, podobna do wyżej omawianego systemu przetrzymywania zawodników, tyle że ograniczona do jednego wybranego gracza na rok, jakkolwiek wolno opatrzyć tym licencyjnym patentem tego samego gracza przez kolejne lata. Licencjonowani zawodnicy są uprawnieni do otrzymywania co najmniej $100 \%$ swoich pensji z poprzedniego roku, a gracze funkcjonujący na zasadzie niewyłącznej licencji mogą przyjmować oferty kierowane do nich ze strony innych drużyn; jeżeli w takim wypadku klub macierzysty zdecyduje się nie występować z równorzędną ofertą, otrzymuje on w zamian ekstra opcje rekrutacyjne.

Ogólnie można stwierdzić, iż zasady transferów w sportach zespołowych stanowią odstępstwo od normalnych zasad zatrudnienia o tyle, że - stwarzając restryktywne warunki przenosin od jednego pracodawcy do drugiego - ograniczają swobodę zmiany pracodawcy przez zawodników.

W przypadku transferu zawodnika, którego nie obowiązują już żadne umowy $z$ danym klubem. Bo klub, na rzecz którego dokonuje się transfer, płaci opłatę transferową; jednak w odniesieniu do graczy do 23 roku życia klub rekrutujący zawodnika musi uiścić opłatę w zamierzeniu wyrównującą koszty szkolenia poniesione przez wszystkie kluby, które uczestniczyły w formowaniu jego siły roboczej. W typowym przypadku transferu wynikającego z rozwiązania umowy przed czasem klub, który dany zawodnik chce opuścić, godzi się na wcześniejsze rozwiązanie umowy zawiązanej z graczem, co oznacza, że klub przejmujący wpłaca opłatę transferową, mającą rekompensować klubowi oddającemu zawodnika zgodę na wczesne zakończenie kontraktu. Ponadto ten pierwszy uiszcza tzw. opłatę szkoleniową oraz solidarnościową 
na rzecz klubów, które przyczyniły się do wyszkolenia danego zawodnika. By odwołać się do wcześniejszych uwag dotyczących renty ekonomicznej, rzeczony aspekt omawianych stosunków odnosi się do kluczowego wkładu w wytworzenie danej siły roboczej. Tego typu transfer może także zakładać premie wynikające z warunkowych rekompensat transferowych wpisanych w ww. daną umowę. Na przykład występują klauzule ustalające podział finansowego ryzyka między stronami. Premia może mieć formę udziału w nadwyżce zysku osiągniętego przez klub, do którego przeszedł zawodnik dzięki swoim sportowym dokonaniom lub też klub nabywający zawodnika może zapłacić jego klubowi macierzystemu dodatkowe wynagrodzenie, jeśli strzeli on określoną liczbę goli czy też zagra w określonej liczbie spotkań w czasie danego sezonu, tym samym przekształcając ten ostatni, czyli, mówiąc bardziej precyzyjnie, jego socjoekonomicznych właścicieli we współwłaścicieli środków pracy klubu, do którego wywędrował zawodnik, gdyż to dzięki uruchamianiu tych środków został osiągnięty zysk, którego część przypadła klubowi macierzystemu. Podobnie, porozumienie transferowe może zawierać klauzulę, zgodnie z którą klub przekazujący zawodnika będzie odnosił sprecyzowane korzyści z kolejnych transferów, w jakie może on być zaangażowany. Klauzula taka przewiduje, że klub macierzysty gracza otrzyma pewien procent opłaty transferowej bądź część tych korzyści, które osiągnie klub transferujący go do następnej drużyny. Do kwestii tej powracamy bardziej szczegółowo w następnej części artykułu, tu natomiast wskazując na jeszcze jeden typ transferów określany jako pożyczka, gracz przenosi się tymczasowo z jednej drużyny do drugiej, pozostając jednak na umowie ze swym pierwotnym pracodawcą. Wypożyczenie takie może być pożyczką darmową niepociągającą za sobą żadnych płatności lub pożyczką połączoną z obietnicą przyszłego transferu. Pożyczki wszelkiego rodzaju podlegają „uspołeczniającym” warunkom, o jakich była wyżej mowa. Kolejnym rodzajem transferów jest transfer zamienny albo barter, w którym kluby wymieniają się pomiędzy sobą kontraktami swoich graczy. Zamiana może, choć nie musi zakładać płatności transferowych.

Kolejny kamyczek do ogródka ekonomii neoklasycznej stanowi fakt, że rynek transferowy w sportach drużynowych jest podzielony na kilka segmentów ${ }^{12}$, odbiegając od wyidealizowanego schematu lansowanego przez tę pierwsząa.

Zasadą różnicującą poszczególne segmenty jest m.in. pozycja stron procesu przetargowego. Niezależnie zatem od rodzaju obowiązującego reżimu prawnego, poza najwyższym segmentem „supergwiazd”, „zmiana klubu jest często narzucana i rzadko jest dokonywana na zasadzie osobistego wyboru", co potwierdza nie tylko

12 KEA-CDES, op.cit. 
fakt utrzymujących się w praktyce ograniczeń własności siły roboczej, lecz także konieczność odróżniania prawnego i socjoekonomicznego punktu widzenia.

Egzemplifikacją tego, iż nawet piłkarskie supergwiazdy w praktyce tracą częściowo własność swej siły roboczej na rzecz właścicieli warunków pracy, jest następujący autentyczny fakt: wartość transferowa, albo bardziej precyzyjnie wartość wymienna siły roboczej piłkarzy jest dziś traktowana jako gwarancja bankowa przez instytucje finansowe, którym grozi niewypłacalność. Oto poważna gazeta „Zuddeutsche Zeitung" donosi, że najdroższy piłkarz w historii (Cristiano Ronaldo) może obecnie posłużyć jako gwarancja wypłacalności hiszpańskiego banku. Konkretnie, grupa kas oszczędnościowo-pożyczkowych Bankia, która sfinansowała zakup przez Real Madryt wspomnianego portugalskiego piłkarza, stara się obecnie o pożyczkę z Centralnego Banku Europejskiego. W odpowiedzi na żądanie zabezpieczenia ze strony tego ostatniego Bankio zaproponowało Ronaldo oraz brazylijskiego piłkarza Kaka, również grającego dla Realu. W 2009 r. Real pożyczył 76,5 mln euro, by uregulować opłaty transferowe wynoszące $100 \mathrm{mln}$ euro na rzecz Manchester United i 60 mln na rzecz Milan AC. Czy doczekamy się sytuacji, w której CBE sceduje prawa do jednego ze swych sportowców?, zastanawia się monachijski dziennik. „Teoretycznie jest to jak najbardziej możliwe. Bankia musiałaby wpierw utracić wypłacalność. Następnie Real musiałby przestać się wywiązywać z obsługi swego długu, zabezpieczonego przez przychody z reklam i praw medialnych.

\section{Własność strony trzeciej}

Taką oficjalną nazwę TPOthere nosi kolejny mechanizm ograniczający własność siły roboczej piłkarzy. Jeśli poprzednio porównywano ograniczenia nałożone na własność zawodniczej siły roboczej ze stosunkami feudalnymi, to w obecnym przypadku bardziej stosowna wydaje się analogia do niewolnictwa. I też w rzeczy samej odpowiedź na pytanie, dlaczego Anglia jako jeden z niewielu krajów (obok Francji i Polski) wydała zakaz TPO, dobrze wyraża przyrównanie przez prezesa Premier League, Richarda Scudamore'a, praktyki kupowania przez inwestorów udziałów w piłkarzach do znanego z historii „niewolnictwa kontraktowego” (2015).

To, co z punktu widzenia danego klubu może wyglądać jak zwykła transakcja (w końcu indywidualny lub instytucjonalny inwestor dostarcza jedynie funduszy w zamian za nabycie praw do najwidoczniej potrzebnego mu piłkarza, uzyskując tym samym prawo do części zysków z jego transferów), może przedstawiać się zupełnie inaczej z punktu widzenia przeciwległego końca transakcji, co dokumentujemy poniżej. 
Radamel Falcao został kupiony przez Atlético Madryt od portugalskiego Porto za $40 \mathrm{mln}$ euro, przy czym kolejne $10 \mathrm{mln}$ stanowiły potencjalne zapłaty premiowe, co uczyniło zakup tego gracza najdroższym w historii klubu. Kontrowersyjność tej transakcji polegała na tym, że Atlético było klubem biednym i po uszy zadłużonym. Ponieważ klubu nie stać było na zakup Falcao, madrycki klub wszedł w porozumienie z Doyen Sports Investments, prywatnym funduszem, którego misję stanowi alternatywne finansowanie klubów i spółek piłkarskich. Doyen zgodził się uregulować płatności, na które klub nie mógł sobie pozwolić, w zamian uzyskując 50\% praw do piłkarza. Znaczyło to, że Doyen był odtąd uprawniony do znaczącej porcji zysków z kolejnych transferów Falcao, co stanowi sedno opisywanego systemu.

Wystąpiwszy w 90 meczach, Falcao znowu znalazł się na rynku, jako obiekt bardzo różnej jednak od poprzedniej transakcji; „trzecia strona” postanowiła sprzedać piłkarza temu, kto da najwięcej, wystawiając go na aukcję, bez oglądania się na życzenia samego zawodnika czy klubu. Sprawa ma się tak, że „Doyen Sports Investment posiada Falcao na własność. Wystawili oni go na aukcję, posługując się jego sportowymi osiągnięciami jako reklamową przynętą. W oczekiwaniu na krocie, jakie przyjdzie zapłacić jednemu z ustawiających się w kolejce inwestorów, na samą myśl o czym ślinka nabiega im do ust, nie biorą oni wcale pod uwagę samego piłkarza; Falcao nie ma nic do powiedzenia odnośnie tego, co się z nim samym stanie, bo w praktyce nie jest on panem samego siebie. Nawet klub, w którym gra, nie ma w nim większościowego udziału. Gdy klub sprzedaje piłkarza, jest to przynajmniej operacja regulowana zasadami kontraktowymi i humanitarna o tyle, że nie dokonuje się ona za plecami gracza, który często ma możność jej omawiania z zarządem danego klubu oraz klubu nowego. W wielu przypadkach zawodnik, czując się z jakichś powodów niekomfortowo w danej drużynie, sam może poprosić o wytransferowanie lub zwolnienie go z umowy. Natomiast cały ten biznes oparty na własności strony trzeciej ma silny posmak nowożytnego handlu niewolnikami.

Nie było nigdy najmniejszego sygnału ze strony piłkarza lub jego klubu, że ten pierwszy źle się czuje w Atlético. Piłkarz zdobywał dla klubu trofea i walnie przyczynił się do zakwalifikowania się do Ligi Mistrzów"13. Najczęstsza obrona praktyki TPO polega na dowodzeniu, że „wzmaga ona konkurencję w futbolu, pozwalając mniejszym klubom na bardziej równą rywalizację z większymi. Jorge Mendes, superagent reprezentujący m.in. Cristiano Ronaldo, Jose Mourinho i Radamela Falcao, uważa, że zakaz TPO oznaczałby kres wszelkiej konkurencji”.

Biznesmen Kia Joorabchian poważnie zaangażowany w TPO bronił tego mechanizmu, określając go jako „model południowoamerykański”. Jego zdaniem transfery

${ }^{13}$ Madu, Zito, Falcao, Atlético Madrid, third-party ownership and deferred dreams, „Times” June 2013. 
oparte na tym mechanizmie stanowią sposób pozyskania wybitnych graczy przez kluby, których normalnie nie byłoby na nich stać. „Tak więc podnosi on poziom konkurencji”, tłumacząc dalej: „jak to się zdarza zwłaszcza w Brazylii, kluby nie mogą sobie pozwolić na zakup piłkarza. Kontaktują się więc z firmą, bankiem, dużym supermarketem lub osobą zamożną i powiadają: «chcemy pana X. Od was oczekujemy 70, 80, 100\% niezbędnych środków, co pozwoli mu zagrać u nas». Trochę przypomina to transferowe pożyczki międzyklubowe, tyle że w tym wypadku transakcja pożyczki dokonuje się między klubem a trzecią stroną". W rzeczy samej, z geograficznego punktu widzenia „TPO jest powszechnie spotykane w Ameryce Płd. - Brazylii i Argentynie; 90\% praw do czołówki brazylijskich graczy znajduje się w posiadaniu stron trzecich". Ogółem wedle firmy audytorskiej KPMG różni pozasportowi inwestorzy posiadają udziały w sile roboczej 1100 profesjonalnych graczy w piłkę nożną w Europie ${ }^{14}$. Kluby z górnej półki, jak Atlético Madryt i Porto, sprzedawały część lub całość ekonomicznych praw do swoich utalentowanych graczy, używając tych transakcji jako mechanizmu finansowania klubowej kasy. Raport zamówiony przez Stowarzyszenie Klubów Europejskich stwierdza, że owa praktyka jest najbardziej rozpowszechniona w Portugalii, gdzie aż 36\% wartości rynkowej wszystkich graczy należy do inwestorów, a nie klubów. Dla przykładu, niedawny roczny raport FC Porto wskazuje, że do klubu należy $100 \%$ całości ekonomicznych praw transferowych w stosunku do zaledwie siedmiu spośród liczącej dwadzieścia dziewięć osób drużyny. Te robiące wrażenie liczby nie powinny jednak zwieść nikogo co do rzekomych walorów TPO tak zawzięcie bronionych przez zwolenników i beneficjentów systemu.

W charakterze kontrdowodu można zwrócić uwagę na podłoże pozyskania przez klub West Ham United dwóch nabytków po linii TPO: Carlos Tévez i Javier Mascherano zostali przetransferowani z brazylijskiego klubu Corinthians w sierpniu $2006 \mathrm{r}$. Jeden z wysokiej rangi angielskich urzędników określił tę transakcję jako „Żenujący handel młodymi ludźmi, który wyrywa trzon klubom usiłującym formować graczy", co bezpośrednio uderza w przytaczany powyżej zabarwiony jednostronnym optymizmem opis TPO. Dnia 22 grudnia 2014 r. Światowa Federacja Piłki Nożnej FIFA wydała generalny zakaz TPO, wzbraniając, szczegółowo mówiąc, jakiemukolwiek inwestorowi niebędącemu klubem piłkarskim partycypowania w korzyściach z transferu. Zakaz wszedł w życie od 1 maja 2015 r., przy okresie przejściowym zezwalającym na realizację do końca, przez okres 12 miesięcy, na przewidzianych warunków wszystkich umów TPO popisanych przed 1 stycznia i 31 kwietnia. Implikacje powyższego zakazu są stale niejasne, ale wielu komentatorów jest zdania, że głównym

14 R. Mangit, How does third-party ownership in football work?, „Talk Sport” 2014. 
jego efektem będzie sprowadzenie praktyki (pod inną nazwą) do podziemia, „gdzie będzie ją tym trudniej namierzyć i regulować" ${ }^{15}$.

\section{Zakończenie}

Z uwagi na ograniczenia objętości tekstu wielu wątków nie dało się zanalizować w takim zakresie, jaki sam autor uznałby za optymalny. Tym niemniej wydaje się, że artykuł spełnił swoje zadanie, dowiódł, jak płodna poznawczo jest aparatura teorii klas i własności. Analizy dokonane za jej pomocą pozwoliły postawić wiele oryginalnych na tle dotychczasowej literatury tez, zarówno natury pozytywnej, jak i polemicznej (to ostatnie dotyczyło m.in. obiegowej kategorii renty ekonomicznej czy jej mielizny starano się odsłonić). Pośrednio wykazano, jak elastycznym narzędziem badawczym jest teoria klas, wbrew potocznym opiniom będąca antytezą dogmatycznego schematyzmu, co w odniesieniu do problematyki artykułu wyraziło się nakreśleniem zróżnicowanej panoramy sytuacji klasowej zawodników, którzy okazują się należeć do różnych klas, zarówno pracowniczych, jak i właścicielskich. Obraz uzupełnia mozaika układów własnościowych związanych przede wszystkim z siłą roboczą zawodników kształtujących się na bazie transferów, z czyich własnościowego znaczenia obiegowa myśl publicystyczna zdaje sobie niejasno sprawę, jak o tym świadczą przytoczone w tekście sformułowania, lecz do pełnego objaśnienia których niezbędna jest naukowa teoria socjoekonomicznej własności.

\section{Literatura}

Badenhausen K., The World's Highest-Paid Athletes, „Forbes” 6 October 2015.

Beesley C., How to Estimate the Cost of Starting a Business from Scratch, „Small Business Administration" 2015.

Brown Ch.B., Player salaries and economic rents, „Monday” 12 July 2010, SmartFootball.com Conn D., Questions for Chelsea over links to third-party ownership of players, „The Guardian" 30 January 2015.

15 A. Krishnan, Explaining third party ownership and how banning it affects football's crazy transfer market, f.Firstplace.com, 20 April 2015. 
Davidson J., Unpaid player salaries add to uncertainty for Mountain Lions, UFL. Sacramento Bee, „Retrieved” 10 October 2012.

Free Online Dictionary.

Krishnan A., Explaining third party ownership and how banning it affects football's crazy transfer market, f.Firstplace.com, 20 April 2015.

KEA - CDES, Study on the economic and legal aspects of transfers of players, January 2013.

Lenin W., Dzieła, t. 29, KiW, Warszawa 1956.

Madu, Zito, Falcao, Atlético Madrid, third-party ownership and deferred dreams, „Times” June 2013.

Mangat R., How does third-party ownership in football work?, ,Talk Sport” 28 September 2014.

Manove, Lecture 17: Economic Rents and Rent Seeking, EC101 DD \& EE 2015.

Marks K., Kapitał, t. 3, cz. 2, KiW, Warszawa 1959.

Piascik A., The Best Show in Football: The 1946-1955 Cleveland Browns, Taylor Trade Publishing, Lanham, MD 2007.

Ronaldo in the bailout fund. Presseurop, „SuddeutscheZeitung” 26 July 2011.

SBA, Starting a Business. How to Estimate the Start-up Cost of Starting a Business from Scratch, SBA gov. accessed, 10 August 2015.

Settimi Ch., The World's Highest-Paid Soccer Players, „Forbes” 21 August 2014.

Sorensen A., Towards a Sounder Basis for Class Analysis, „American Journal of Sociology” 2000, Nr 105(6), s. 1523-1558.

Tittenbrun J., A critical Handbook of 'Capitals' Mushrooming Across the Social Sciences, Lambert Academic Publishing, Saarbrucken 2013.

Tittenbrun J., Anti-Capital (Human, Social and Cultural) The Mesmerising Misnomers, Ashgate, Farnham 2013.

Tittenbrun J., Concepts of Capital. The Commodification of Social Life, New Transaction Publishers, Brunswick, NJ 2014.

Tittenbrun J., Economic sociology Revisited, Cambridge Scholars Publishing 2011.

Tittenbrun J., Gospodarka w społeczeństwie. Zarys socjologii gospodarki i socjologii ekonomicznej w ujęciu strukturalizmu socjoekonomicznego, Zysk i Ska, Poznań 2012.

Tittenbrun J., Kolonizacja nauki i świata przez kapitat, Zysk i Ska, Poznań 2015.

Tittenbrun J., Ownership and Social Differentiation. Understandings and Misunderstandings, Lambert Academic Press, Saarbrucken 2011.

Weber M., Gospodarka i społeczeństwo. Zarys socjologii rozumiejacej, PWN, Warszawa 2002.

World Bank, Starting A Business 2015.

Wright E., Class, Exploitation and Economic Rents: Reflections on Sorensen's Better Foundations, „American Journal of Sociology” 2000, Nr 1056, s. 1559-1571. 


\section{Ownership and Class Position of Players in Professional Team Sports}

Although social sciences do not ignore sports altogether, they do not attempt to analyse the class position of players in team sports. Therefore, the aim of this paper is to conduct such analysis. The starting point is introduction of the idea of socio-economic class based on the theory of economic ownership understood as rent. As the term "economic rent" is used in neoclassical economy, I explain the differences between that approach and the one used in this paper. Building on theory and on empirical data on the earnings of players, I conclude that while the sports elite undoubtedly represent ownership and bourgeoisie class, the less financially attractive leagues or less earning players represent workers owning labour and sometimes that ownership is severely limited.

Keywords: social class, Marx, Weber, ownership, sport, team sports, economic rent, transfer market

\section{La propriété et la classe sociale des joueurs professionnels dans les sports d'équipe}

Le but de l'article est d'analyser la propriété et la classe sociale des joueurs professionnels dans les sports d'équipe. L'article introduit le concept de classe socioéconomique, basée sur la théorie de la propriété économique. L'article analyse les données empiriques relatives à la rémunération des joueurs. Cette analyse montre que les jouers d'élite représentent la propriété et la classe bourgeoise, tandis que ceux moins populaires ont des revenus inférieurs et appartiennent à un groupe socio-économique plus bas.

Mots-clés: la classe sociale, Marx, Weber, la propriété, les sports déquipe, la pension économique, le marché des transferts 


\section{Классовое и владельческое положение игроков в профессиональном командном спорте}

Хотя в общественных науках уделяется внимание спорту, но не хватает анализа классовой позиции игроков командных видов спорта. Таким образом, цель данной работы - провести анализ такого рода. Отправной точкой является идея социально-экономического класса, основанная на теории экономических прав собственности, т.е. ренты. Поскольку термин “экономическая рента" используется в неоклассической экономике, автор объясняет различия между этим подходом и применяемым в статье. Базируясь на теории и на эмпирических данных о доходах игроков, автор приходит к заключению, что в то время как спортивная элита, несомненно, представляет собой собственность и буржуазный класс, менее финансово привлекательные лиги или менее зарабатывающие игроки являются владельцами рабочей силы, а иногда эти права собственности бывают строго ограничены.

Ключевые слова: социальный класс, Маркс, Вебер, собственность, спорт, командные виды спорта, экономическая рента, трансферный рынок 